\title{
Critical Peacebuilding and the Dilemma of Difference: The Stigma of the 'Local' and the Quest for Equality
}

\section{Introduction}

A number of critical approaches have emerged in peacebuilding ${ }^{\mathrm{i}}$ scholarship asking for a genuine engagement with the local level, actors and agency. ${ }^{\text {ii }}$ This literature "emphasise[s] the need to listen to the voices from below" and "criticise[s] international peacebuilding agendas for ignoring the local beyond its rhetorical inclusion in policy papers". iii For these scholars, the problematic outcomes of peacebuilding are "often re-read as the resistance of indigenous ways of life and knowledges, which should instead be understood and empathised with". "Their goal is thus to 'challenge' simplistic and reductionist understandings of the local as a passive 'recipient' of peacebuilding interventions." Critical peacebuilding scholars advocate "a more empathetic, responsive, culturally sensitive, and ultimately radical peace encompassing the local, indigenous, and quotidian experience, especially that of the subaltern categories, within conflict affected spaces and societies". ${ }^{\text {vi }}$ As with any label, of course, this group of scholars is characterised by a great variety of views. ${ }^{\text {vi }}$ Nevertheless, they are united by their critical stance towards current peacebuilding practices (hence the use of the label 'critical' which does not refer here to Critical Theory nor to non-mainstream approaches) and they focus on the ways a better inclusion and/or understanding of the local could improve peacebuilding outcomes. As such, this article focuses on the third strand of critical peacebuilding literature as identified by BarguésPedreny, i.e. a group of scholars seeking "to engage more generously with 'difference"' and the local in the context of peacebuilding. ${ }^{\text {vii }}$

This scholarship has been criticised for the way it reproduces binaries and systems of classification of the local versus the international that are detrimental to the eventual respect and equality that these scholars want to ensure. ${ }^{\text {ix }}$ Despite recognising this limitation, most critical scholars remain convinced that the best way to improve peacebuilding is to genuinely respect the local by ensuring that it is adequately understood. As a consequence, the primary goal of scholars 
interested in critiquing current peacebuilding practices is to find adequate ways to study the 'difference' of the local. This goal, they argue, would enable interveners to avoid ethnocentrism (and thus respect the local) and would improve the prospects of peacebuilding interventions. This line of investigation seems intuitive: how to critique the universalism of dominant forms of peacebuilding if not by looking at what is not considered as universal - the local - and at ways this 'non-universal' differs or resists? Why not using this 'local difference' as a starting point if one wants to achieve a genuinely non-hegemonic form of peace? And how to respect the local in peacebuilding except by focusing on 'it' and on 'its' identity?

This article shares these concerns about finding a better way to engage with the local in peacebuilding interventions but it makes the counter-intuitive claim that focusing on the local as a way to emancipate 'it' cannot deliver respect and equality but instead will produce further exclusion and stigmatisation (the very problems that critical peacebuilding scholars are trying to solve). On the one hand, critical peacebuilding scholars have greatly contributed to revealing the universalist assumptions that inform peacebuilding. Indeed, they have studied the local empirically in order to question the impact of the 'one-size-fits-all' practices of peacebuilding and have often noted the disconnection between universalist peacebuilding practices and local realities. On the other hand, however, the respect for the local that critical peacebuilding scholars want to achieve takes the form of an emphasis on its characteristics and identity. If such an approach has had some positive outcomes, it has also contributed to recreate a stigma attached to the local. Indeed, the local is often identified as 'different' without the structures of power that enabled this identification being interrogated or revealed. This means that 'difference' becomes understood as an inherent trait of the local and that the institutional and normative frames that are necessary for the identification of this 'different' local are silenced. The worldviews and arrangements of peacebuilding thus continue to be accepted and reproduced even through a focus what is supposedly external to them: the 'different' local. As a response to this problem, I discuss in this article three possibilities to improve our understanding of difference in peacebuilding: first, to focus on difference as a power relation and not as an attribute of the different person; second, to recognise that the 'difference' of the local is thus 'internal' to peacebuilding (and not a source of external alternatives to the practice of peacebuilding); and third, to reveal the identity of the unstated Self from whom difference is constructed. These alternatives do not run counter to the agenda of critical peacebuilding scholars; in fact, they respond to some of the frustrations that these scholars have themselves identified (and in particular to the often noted difficulty of 'accessing the local'). As such, I offer a sympathetic critique designed to reinforce their research agenda. 
This article is thus a theoretical contribution to peacebuilding scholarship and it focuses explicitly on the way 'difference' is used by these scholars. I do so by building upon Martha Minow's analysis of difference in a legal context. In her research on the way law and society function through the use of dividing and category-making practices, Minow identifies a dilemma of difference. As she explains, "The stigma of difference may be recreated both by ignoring and by focusing on [difference]". This means that the traditional ignorance of difference under a universalist pretence will recreate the inferior positionality and the stigma of the different person. For instance, ignoring the specific situation of women in a patriarchal society will further entrench the inequalities between men and women. But alternatively, the critical approaches designed to tackle inequalities by focusing on difference also recreate a stigma through the insistence on treating the different person differently. Indeed, the different person is identified with (and reduced to) her 'difference', which means that difference is reproduced as a stigma and inferiority (or deviation) even when the primary goal was to emancipate her. The two alternatives of the dilemma identified by Minow are equally present in the field of peacebuilding: while the universalist approaches have largely ignored difference (and thus reproduced the unequal position of the local) the critical approaches studied in this article have advocated a focus on difference at the risk of recreating the stigma attached to the local.

As a response, Minow develops a radically relational approach in which difference is always 'difference from' an unstated 'norm' or 'standard' and in which the central question for critical scholars is no longer 'in what ways is this person different?' but rather 'what existing institutional arrangements' are taken as “an unproblematic background” ${ }^{\mathrm{xi}}$ when 'difference' is identified?' She thus recommends studying 'difference' as emerging from particular social and economic arrangements that are seen and portrayed as natural and neutral. In essence, she advocates an approach to 'difference' that does not emphasise the 'different' Other as the main 'problem' or 'solution' to be investigated and known. Applied to peacebuilding, it means that asking 'who the local is' is counter-productive if it does not also reveal the arrangements that contribute to the identification of the difference of the local. Indeed, and since difference is a "comparative term", the real question becomes that of the "point of comparison" that is left unstated ${ }^{\mathrm{xii}}$ and the power differentials that have contributed to naturalise difference as existing 'out there'. Minow thus offers a good starting point for a field that suffers from a lack of direct engagement with the concept of 'difference' and with the way 'difference' informs peacebuilding research and practice. ${ }^{\text {xiii }}$

This article develops this argument in three sections. First, it explains how critical peacebuilding scholars have advocated a focus on the local as necessary for its respect in peacebuilding interventions, thus reproducing the second alternative of the dilemma of difference. In the 
second section, I briefly outline how the consequences of the dilemma of difference: I focus on the practices of separation and reification that inform the literature and explain how these choices are unavoidable because of the pressure to find and define the difference of the local. In the third section, and building upon Minow's insights, I outline how the question of difference (of the local) can be approached differently (i) by focusing on the institutional arrangements that enabled these particular differences to emerge and become visible; (ii) by therefore considering these differences as internal to the peacebuilding framework (and thus an unlikely source of alternative and emancipation); and (iii) by revealing the position of the unstated Self in the construction of difference.

\section{Focusing on the Local in Peacebuilding Failures, or the Second Alternative of the Dilemma of Difference}

This article focuses on a specific group of scholars who have been critical of the universalist assumptions that characterises current peacebuilding. These scholars do not share the same epistemology, ontology or methodology yet they all agree on the need to recover the local as a legitimate actor of 'her' peacebuilding. Björkdahl and Gusic, for instance, express the necessity "to access "peacebuilding from below" xiv and "to connect with local epistemologies of peace". ${ }^{x v}$ Instead of being discarded, Richmond and Mitchell argue, the local should be fully considered $^{\text {xvi }}$ insofar as it can provide an emancipatory version of peace and some necessary alternatives to the Western-defined paradigm of peacebuilding. As Mac Ginty explains, "a critical local lens can help us escape from the ethnocentrism that is inclined to see the global North as the starting point and everything else relative to it". "xvii Faith is thus placed in the local as a source of change and transformation. Critical peacebuilding scholars also express their dissatisfaction with the first 'turn to the local'; in their own assessment, such a turn is seen as "only operating at the rhetorical and normative levels" xviii or as reproducing problematic assumptions about a rural or traditional local. In contrast, a genuinely emancipatory approach would rely on a better, more thorough, understanding of the local - an understanding that does not privilege the local that fits the expectations of the dominant (and usually Western) peacebuilding paradigm, and an understanding that takes the complexities of the local into account. Indeed, these critical scholars estimate that dominant peacebuilding practices too often reduce the local to a passive recipient trapped in her "particularities, contextuality and lack of mobility". ${ }^{\text {xix }}$ In contrast, the critical peacebuilding scholars that this article focuses on seek to "move beyond this [limited understanding of the] local and find ways in which we can gain a more sophisticated view of what might constitute the local". ${ }^{\mathrm{xx}}$ 
While this assessment of peacebuilding is guided by an interest in preserving diversity against the universalist tendencies of current interventions, it also participates in establishing a specific diagnosis of the 'problem' and thus in orienting the search for 'solutions'. Indeed, such a diagnosis urges us to develop a more specific and more detailed understanding of the local in order to ensure its respect. In effect, the 'problem' posed by the neglect of difference in processes of peace formation would be 'solved' by knowing difference better (and, potentially, including 'it' in the peacebuilding goals and architecture). A first step towards this goal is to acquire more (and more sophisticated) knowledge of the local. Empirical studies of the local are thus flourishing and have greatly enriched the field of peacebuilding. ${ }^{\mathrm{xxi}}$

If the local becomes central and a key element of critique, accessing 'it' is recognised as difficult or even impossible. In fact, critical scholars such as Mac Ginty or Björkdahl and Gusic judge their own achievements severely, noting that the conceptualisation of what 'the local' might mean remains 'light'. xxii This leads Wilén and Chapaux to argue that "very few answers are given as to who these local actors are". xxiii This is not surprising: for critical scholars, and in a manner consistent with their starting points, the local is a flexible and moving target, capable of transformation; it harbours complex and sometimes contradictory identities; it can be situated differently, from the everyday 'kitchen table' to transnational networks; it can be multiple; and it is a construction that relies on perceptions. ${ }^{\text {xiv }}$ This means, as Schierenbeck argues, that "engaging with the local is not something that can be done in haste", ${ }^{x x}$ if it can be done at all. Most also recognise that, ironically, there might not be an object 'local' since every local has already being influenced by other locals. ${ }^{x x i}$ In these conditions, identifying the local becomes a challenging, if not impossible, task. Björkdahl and Gusic, for instance, write that they "have unpacked local agency without pretending to provide more than snapshots of the workings of such agencies and the complexity of exercising agency in post-conflict spaces".xxvii Similarly, Mac Ginty recognises that "this agency [of the local] can be significant, if often difficult to "see". xxviii Some scholars also insist that the local is 'anarchic'xxix and "awkward, constantly changing, and difficult to describe"'. ${ }^{x x}$ In short, critical peacebuilding scholars both emphasise the necessity to know the local and the great difficulties that arise when one tries to access 'it'.

Despite a wide recognition of these limitations, critical peacebuilding scholars continue to emphasise the local as key. One possible explanation for this insistence on the local can be found in the way the possibilities for peacebuilding are restricted to (i) the liberal universalist silencing of the local and (ii) the emphasis on the local as different and as a fundamental starting point for emancipatory politics. These two possibilities correspond to the dilemma of difference identified by Minow, and as Lidén, Mac Ginty and Richmond demonstrate, critical scholars establish their critique as the only alternative to the liberal neglect of the local: 
Two directions lend themselves to the resolution of this debate [in peacebuilding]: further research into more localized understandings of peace that allow for multiplicity or hybridity, human needs, welfare and human security to emerge in a bottom-up manner $(. .$.$) or the continuation of the old 'world federation' project in which the liberal peace is$ refined until it really does become a one-size-fits-all, top-down and transferable blueprint for a universal peace. ${ }^{\mathrm{xxi}}$

In other words, critical scholars advocate an approach centred on the different local contra the liberal, universalist and problematic perspective of mainstream peacebuilding. In doing so, critical peacebuilding scholars reproduce the second alternative of the dilemma of difference: while their objective is to avoid the ignorance and neglect of the local that is typical of traditional universalist peacebuilding, their approaches emphasise difference at the risk of reproducing the stigma attached to it. Indeed, the local is valued precisely because of 'its' difference, a difference that is therefore isolated from the broader framework that enabled its identification in the first place. Such an approach to difference leads to creating a stigma insofar as it leaves in place and reinforces the structures of power through which difference came to exist (i.e. to be considered as relevant). And these structures were the ones that contributed to exclude and stigmatise the local: their ethnocentrism produced a view of the local as irrational and pathological. ${ }^{\text {xxii }}$ Thus, just like equalising conditions between men and women cannot succeed if it only insists on the 'difference' of women - such an approach will reproduce the stigmas attached to what are constructed as 'essentially' feminine characteristics ${ }^{\text {xxxii }}$ - the local should not be valued exclusively through an emphasis on 'its' difference. In essence, valuing the local for 'its' difference "presumes that we all perceive the world in the same way and that we are unaffected by our being situated in it". xxiv Such an attitude silences the differences of power through which difference is defined. Expressed differently: it transforms differentials of power between actors into differences between them. These unequal relations of power are therefore at risk of being naturalised as differences associated with the local.

\section{Recovering Difference, Reproducing Inequality}

By replacing the work of critical peacebuilding scholars into the dilemma of difference, it becomes possible to understand how the focus on the local represents a positive alternative to traditional peacebuilding but can also contribute to reproduce a stigma that these same scholars lamented in the first place. The lack of attention to the ways these differences come to exist means that they are approached as characteristics essentially attached to the local and not as characteristics that acquired meaning through (and in reaction to) specific peacebuilding frameworks and expectations. As such, the likeness that these differences will be stigmatised is high. In this section, I briefly analyse how the stigma is reproduced by two strategies that critical 
peacebuilding scholars are forced to adopt in order to preserve the coherence of their approach: separation and reification.

\section{Separating the Local}

First, portraying the local as one of the solutions to failed peacebuilding practices means that critical scholars have to separate or isolate 'it'. Despite Mac Ginty's claims that "the local and the international are co-constitutive of each other and as such cannot be seen as separate parts of a binary", ${ }^{x x v}$ this form of differentiation clearly informs the practice of researching the local. Indeed, the identity of the local cannot be but different from that of the unstated (and thus universalised or internationalised) Self. Sending, for instance, explains that a genuine engagement with the local will involve "some very difficult normative considerations, not least in terms of how to adjudicate between different and possibly conflicting ends and values". xxxi In a similar way, Björkdahl and Gusic want to critique the vision of the local as passive importer of global norms yet their analysis only challenges these characterisations (global exporter versus local importer), not the local or global character of the actors concerned. ${ }^{\text {xxxii }}$ The concept of 'hybridity' as used in the peacebuilding literature also recreates this sense of separation: indeed, 'hybridity' is understood as the encounter between two (or more) separate and different entities that, through this encounter, will become hybridised. ${ }^{\text {xxviii }}$ For Richmond, for example, hybridity represents "that all important interface between the international liberal position and the local non-liberal Other"; hybridity is in fact seen as opening up "the liberal peace to its so-called nonliberal Others and their agencies, giving rise to an essential negotiation between them". xxix The local is thus Othered in a binary fashion and opposed to the non-local or international. As such, difference is used as a key criterion to indicate the level of 'localness' of the local under consideration. In other words, the local exists through 'its' difference only.

The local is thus separated by being portrayed as different. This way of understanding 'difference' serves to hide the unstated reference to an international, universalised-yet-Western Self. Through this fiction the local seems to be standing on 'its' own, as a separate entity: 'it' is isolated from the broader context which nevertheless made 'its' difference exist in the first place. As a consequence, critical peacebuilding scholars approach the local with an assumption of difference that also characterises liberal peacebuilding and that contributes to reinforce the stigma attached to the local. Lidén, Mac Ginty and Richmond for instance estimate that "Liberal peacebuilding may need to investigate ways of not just extending its moral responsibility over the citizen or subject or the non-liberal other, but engaging with other, probably non-Western/ 'modern' ontologies and epistemologies". ${ }^{\mathrm{xl}}$ A clear separation between the liberal international and the different local is re-established as an analytical assumption. In the same way, Mac Ginty writes that "the 
liberal peace has managed to co-opt as its agents many of those actors that one would expect to champion alternative (including traditional and indigenous) modes of peace-making". xli Once again, the local is Otherised from the start and from the perspective of the impersonal and universalist 'one' who 'would expect' to find difference and alternative in the local. This is an example of the second alternative of the dilemma of difference: trying to avoid universalism and its ignorance of the local, critical scholars reproduce the fiction of an inherently 'different' local a separate sphere that is different outside of the frames and practices that made this difference exist in the first place.

\section{Reifying the Local}

The second aspect leading to the reproduction of the stigma of difference is the reification of the local. Critical scholars in peacebuilding insist that the local should be approached as constantly changing and adapting. ${ }^{\text {xli }}$ For Schierenbeck, "There is a need to challenge the notion of the local as static and a victim of what is being done to it". "xliii In addition, the local is conceived as complex, multiple or hybrid. For Schaefer, therefore, the local is not "monolithic" xliv and as argued by Donais we should not assume a 'coherence' that is at odds with 'the social complexity inherent in any social order". ${ }^{\text {lv }}$ Yet this insistence on fluidity and transformation conflicts with the necessity to identify the local as a source of emancipatory possibilities. Guided by this objective, critical peacebuilding scholars emphasise 'culture' in a way that contributes to reification. For them, peacebuilding needs to understand, respect, and study the 'culture' of the local. In fact, the identity of the local is intimately linked to her culture. Collective agency and political organisation, for Richmond, originate from culture. ${ }^{\text {xlvi }}$ And a proper understanding of this culture offers the patient and dedicated scholar the key to understand and thus respect the local:

[achieving a genuine turn to the local necessitates] a more serious analysis of the role of culture in peace-making and a reining in of any tendency to romanticize the 'traditional' or 'indigenous'. It would also benefit from a dissection of orthodox approaches to peacemaking to identify those parts of peace-making processes that could usefully be replaced or augmented by indigenous or traditional practices. .lvii $^{\text {. }}$

In contrast to liberal peacebuilding where culture, custom, religion and identity are often purposefully ignored, dviii critical peacebuilding scholars promote a 'thorough' engagement "with the local context, culture, history, needs as well as rights and institutions". ${ }^{\text {xlix }}$ According to Donais and Richmond, for instance, taking into account the historical and political culture of the local would help avoid the colonial logics of liberal peacebuilding ${ }^{1}$ and offer the possibility of a genuine respect of the local. 
The local is thus defined by her culture - or, expressed differently, local cultures need to be at the centre of the analysis if one is to improve the outcomes of peacebuilding. Through this insistence, the local is reified as an expression of her - sometimes hybrid - culture. Repeatedly, therefore, critical peacebuilding scholars turn to anthropology or area studies as the most adapted disciplines in order to study the culture of the local. ${ }^{\text {li }}$ Schierenbeck, for instance, highlights the "need for enhanced collaboration between peace research and area studies to reach a thicker description and more thorough contextualisation of the object of analysis". "ii Felix da

Costa and Karlsrud similarly deplore the lack of "anthropologically informed and long-term research that emphasises the need to understand local meanings and context". liii A specific (and restricted) understanding of anthropology and area study is thus portrayed as a solution to recover the cultural local. As a result, the local is largely de-politicised: Wanis-St. John considers 'indigenous forms of conflict resolution' as "victim-centered, participatory, egalitarian, consensual, and restorative of communal harmony"liv whereas Visoka and Richmond insist on the necessity of 'postexclusionary politics' and on finding "an emancipatory framework of peace as nondomination rooted in local peace-enabling agency". lv

In sum, these various attempts at respecting the local are undoubtedly guided by the desire to recover it as a source of alternatives and emancipation and by the ambition to disrupt the reproduction of Eurocentric and universalist peacebuilding practices. This way of approaching difference served as a useful starting point for a critique of peacebuilding. These attempts indeed represent a genuine progress when compared to a more limited and instrumentalised inclusion of the local in peacebuilding. ${ }^{\text {lvi }}$ Yet the imbalances of power in which peacebuilding operates are not radically transformed insofar as the stigma attached to the local is reproduced. This can be seen as counter-intuitive: how can scholars dedicated to respecting the local unwillingly contribute to reinforce such an unequal relationship? Following Minow, I argue that separating and reifying the local as different (or portraying difference as an inherent quality of the local) forces us to see this different local as deviating from an unstated standard. However positive this difference is portrayed - and it is often recognised by critical scholars as a positive alternative to universalist peacebuilding - the stigma attached to the local is re-affirmed. In simplified terms, it means trying to portray the local as equal by insisting on everything that differentiates her from the unstated standard/Self. Indeed, and because local differences are taken as existing 'out there' (and not in relation to a peacebuilding frame of reference that is left unstated), local actors are condemned to appear as deviating from the norm. The silencing of the way difference came to exist helps explain why separation and reification usually reappear even in critical analyses. ${ }^{\text {lvi }}$ As such, the standard of peacebuilding is preserved through the critique because this critique builds upon it in order to identify alternatives in the 'different' local. It means trying to disrupt dominant arrangements by using differences that are only salient through these arrangements. 
The self-defeating logic of this 'dynamic of difference ${ }^{\text {lviii }}$ is clearly apparent: once otherised, the local cannot be easily considered as a valid alternative. These attempts have thus been effective to disrupt the fiction of peacebuilding as a working 'one-size-fits-all' enterprise but crucially, and as the next section will argue, the possibilities for understanding 'difference' should be broadened to the alternatives outlined in this article.

\section{Suggestions for Researching Difference Differently in Peacebuilding}

In this last section, I discuss in more depth how the quest for the local has hindered the development of other important ways through which peacebuilding can be questioned. To a certain extent, the question of the local has acted as a diversion to other critical projects: efforts have been focused on knowing the local and 'its' difference and on improving our methods to access it. Revealing the local has thus been a 'new frontier' for critical peacebuilding research, and it has served a useful purpose: to reveal the inadequacy of universalist frameworks when confronted to diversity. At the same time, however, the structures and the architecture of peacebuilding in which such differences matter (and seem relevant) are left in place and reproduced by these critical approaches. We thus need to come back to questioning the political goals and assumptions guiding peacebuilding instead of deploring the supposed lack of access to a genuine local that could re-orientate peacebuilding. In the reminder of this section, I will explore how such a re-focus can be informed by Minow's insights on difference. These suggestions are not intended to provide a comprehensive new research agenda. Instead, I outline three possibilities that can form part of an effort to look at difference differently: focusing on the conditions that make 'difference' exist; recognising (as a consequence) that the 'difference' of the local is always internal to (because produced by) peacebuilding; and finally developing a reflexive approach towards the un-stated Self. The overall goal is not to deny the existence or reality of difference but rather to reveal how its relevance always depends on a wider context (and thus how a narrow focus on the different Other is insufficient and counter-productive).

\section{Institutional Arrangements and the Identification of Difference}

One avenue highlighted by Minow in her work on difference is to re-socialise and re-connect the existence of difference to the ways this difference comes to exist. As she explains, we need to consider "existing institutional arrangements as a conceivable source of the problem of 
difference rather than as an unproblematic background". lix The 'problem' is thus no longer only to discover who the local is or what alternative it can offer but also to show how it came to be taken as different (and thus as a possible source for alternatives) in the first place. As Minow argues,

Difference may seem salient, then, not because of a trait intrinsic to the person but because the dominant institutional arrangements were designed without that trait in mind - designed according to an unstated norm. ${ }^{1 \times}$

This should not be understood to mean that differences do not exist. Rather, it is the way a near infinity of differences is reduced to only a few 'key' differences that is important. As an example, the difference of the local is sometimes equated to its informality or traditional aspect; some of the scholars mentioned in this article describe the local as the 'everyday', lxi as the 'organic, traditional or indigenous', lxii as the 'infrapolitical dimension', lxiii or as the 'community' level. ${ }^{\text {lxiv }}$ Only through a peacebuilding framework expecting the presence of 'normal(ised)' and so-called 'formal' structures of social relations are such traits (traditions, infrapolitics) recognisable and identifiable (and then categorised as different). Whereas the stated goal is to reveal difference in order to enable its respect, it seems clear that a stigma is reproduced by identifying the local as different from 'normal' politics. Hence, trying to include the local while emphasising 'her' difference is bound to fail insofar as this difference continues to be treated as existing independently of the specific frames that enabled it to exist. In fact, this local is only different in the way depicted by critical scholars insofar as it is inscribed into patterns of relations that peacebuilding promotes and that usually go unrecognised. Whereas "the excluded seem not to fit because of something in their own nature", ${ }^{\mathrm{kx}}$ this difference only exists in relation to an accepted frame of reference. In addition, locating difference in the local runs the risk of arbitrarily focusing on one or a few characteristics to the exclusion of others. Indeed, differences are almost infinite and restricting the local to its ethnic, geographic, social, gender, religious... difference is necessarily restrictive. Which of these matter and are inscribed as 'differences' depends on the institutional arrangements in place at any given time, and these arrangements can only be revealed when one 'zooms out' of these specific differences of the local.

Interestingly, this goal has been mentioned by critical peacebuilding scholars themselves. As argued by Mac Ginty and Richmond "Hybrid forms of peace make clear that inequalities in power require identifying, carefully dismantling and replacing in any positive hybrid peace order". ${ }^{\text {xvi }}$ These inequalities, however, are rarely explored or too often limited to inequalities among local actors. Indeed, and as Nadarajah and Rampton argue: 
by directing attention to localised interactions, as opposed to overarching structures, accounts of hybridity are disembodied from the totality - marked by material social and political inequalities - in which it is located, thereby tending to obscure the power relations and hierarchies constituting domineering orders such as capitalism and racism. ${ }^{\text {lxvii }}$

If critical scholars have thus recognised the necessity to develop a broader analysis that goes beyond the characteristics attributed to the local, these ambitions are often restricted to analysing power relations between locals. In contrast, I argue that the approach outlined in this article can help us imagine more egalitarian encounters by refocusing our attention to the overall imbalances of power that characterise peacebuilding. The question 'who is the local?' is thus only essential when put in relation to the broader institutional arrangements that determine how identities and differences emerge in the first place. Differences matter, therefore, but they matter as relations (and not as inherent attributes). This is important for both scholars and practitioners to consider: actors involved in peacebuilding are defined (at least partly) by their position in the overall peacebuilding encounter. An alternative critical route needs to explicitly recognise that the question of difference (i.e. the fact that the local continues to be excluded from peacebuilding practices) cannot be solved at the level of the 'different' local if it wants to avoid the risk of reproducing the binary thinking and differentiation strategies built in peacebuilding (and on which the practice of peacebuilding is dependent for its own coherence and legitimacy). This alternative also goes beyond the idea of a vertically-integrated peacebuilding in which top-down and bottom-up processes are linked. As Donais argues, “a strategy of focusing on the local as a site of peacebuilding may only make sense, and may only be sustainable, if it is embedded within a larger strategy of vertical integration". ${ }^{1 x i i i}$ Instead of questioning how the peacebuilding enterprise creates the local itself, such an approach mainly seeks to more effectively involve the local in peacebuilding (thus leaving intact its portrayal as 'different').

\section{Local Differences are Internal to the Power Dynamics of Peacebuilding}

Second, and as a consequence, the local cannot be seen as a direct source of alternatives for peacebuilding practices that are seen as ineffective. This tendency is particularly noticeable in publications that combine very diverse case-studies of 'the' local (a plurality treated as singular). Yet alternative peacebuilding practices are not necessarily found in the local. Since these local differences are identified in relation to peacebuilding (or in reaction to it), they are 
only relevant in and for an already existing peacebuilding framework. Applied to peacebuilding, this means that scholars and practitioners should remain interested in differences and should continue exploring them but should not treat them as realities or variables that can necessarily improve peacebuilding because they are independent from it. Identifying contestation to peacebuilding in a particular local context, for instance, and attributing it to the existence of different values held by the local population only offers a limited alternative insofar as these different values are identified as a response to peacebuilding. Transforming peacebuilding requires more than local adjustments that necessarily remain marginal insofar as they emerge as reactions to the dominant frameworks of peacebuilding and have to counter the stigma attached to their characterisation as 'different'.

More importantly, perhaps, and as long as the different person is seen as key because she exists as an 'outsider', power dynamics are misrepresented or kept hidden from view. In fact, differentials of power are translated into or silenced as differences. Difference (and not power) becomes the question to be investigated, as if the different person was different independently of the power dynamics that surround her and the Self. As argued by Minow, attempts at studying difference as an inherent characteristic means "preserv[ing] the pattern of relationships in which some people enjoy the power and position from which to consider - as a gift or act of benevolence - the needs of others without having to encounter their own implication in the social patterns that assign the problems to those others". "xix In peacebuilding research, this means that 'discovering' the local is a first but always incomplete step if not reconnected to the power relations that gave rise to this different local, and that the 'differences' identified in the process tell us more about the power relations that inform peacebuilding than about the actually existing local(s). Difference as a conceptual tool can still be used but in a reverse manner: instead of informing us about the 'different' person (and providing us with an 'external' variable or reality that can be used as an alternative), "perceptions of difference can become clues to broader problems of social policy and human responsibility". ${ }^{\mathrm{kx}}$ Discovering difference is thus a way to shed light on power dynamics and on the place of the Self in perpetuating them.

\section{Revealing the Unstated Self}

Finally, another suggestion for peacebuilding scholarship is to adopt a more reflexive approach towards the unstated Self. Indeed, "The differences we identify and emphasize are expressions of ourselves and our values". "xxi Since difference never exists on its own and is thus not a trait inherent to the 'different' person, it is always constructed from somewhere and with a specific norm in mind. This norm is then normalised (and universalised) by being kept implicit. Classifying people as different (or identical) is thus more than simply reporting pre-existing 
characteristics that exists 'out there'. It involves attributing from the perspective of the Self a specific importance to some characteristics - making them matter and materialise. Hence, maintaining the Self implicit tends to promote a view of differences as lying "within people [and] obscures the fact that they represent comparisons drawn between people, comparisons that use some traits as the norm and confirm some people's perceptions as the truth while devaluing or disregarding the perspective of others". lxxii

As a response to these tendencies, peacebuilding research and practice need to make explicit what is kept implicit: the position and role of the unstated Self researching and acting in peacebuilding. Such a strategy is complex and somewhat counter-intuitive: researching difference usually means offering more space to the different person rather than to the Self. In addition, differences can appear as undeniable realities that exist outside of our worldview precisely because they are different. It is thus the role of the Self in the 'encounter' with difference that needs to be questioned. Critical scholarship has hinted at the idea: Mac Ginty, for instance, wrote that "the local is a social construction" and that "In order to find the local we need to examine the ways in which we think" "lxxiii. But such an ambition has not been fully realised by clarifying the position of the acting and researching Self. In particular, scholars and practitioners need to consider the way identities are co-constituted and therefore the fact that the local does not pre-exist its encounter with the Self. Only once this step is taken can a different strategy emerge: "What we do with difference, and whether we acknowledge our own participation in the meaning of the differences we assign to others, are choices that remain". lxxiv This reflexive strategy contributes to avoid blaming the local or victimising 'it' as a passive expression of 'its' own culture. If difference is denaturalised by making the role of the Self explicit - and not by making the 'identity' of the 'different' local known - then peacebuilding research (and practice) can regain some latitude to design alternative strategies through which all actors can be respected.

\section{Concluding Discussion}

This article has interrogated some of arguments made by critical peacebuilding scholars through a framework that problematizes the idea of difference. As shown, these scholars reproduce the second alternative of the dilemma of difference, i.e. they put the emphasis on the difference of the local as a way to establish more equal relations. Such a strategy is well-intentioned insofar as it explicit engages with the undeniable diversity faced by peacebuilding. It is also useful as a first critical step against universalist approaches. Yet it risks reproducing the stigma attached to difference even when scholars try to avoid it. The local is indeed valued because of 'its' 
difference, a difference that only becomes salient through the use of dominant peacebuilding frames. This is how the stigma is unwillingly reproduced and how the supposedly emancipatory role attributed to the 'different' local is always compromised. In contrast, I have argued that difference should not be approached as an external variable that exists 'out there' (independently of our assumptions and expectations) and that can be discovered in order to improve peacebuilding. I have outlined how such a position could help solve some of the deadlocks identified by critical peacebuilding scholars.

This different research agenda, however, will have to tackle two difficulties. First, how far can such a critique be conducted and implemented in the frame of peacebuilding? Minow's reconfiguration of the 'problem' of difference is particularly ambitious: ultimately, for her, dealing adequately with difference is not reduced to enabling the adaptation and inclusion of the different person into the existing arrangements but should rather question these arrangements and the 'realities' they create. How far, however, can the peacebuilding architecture and project be reconfigured away from the universalist demands of the liberal peace? Is peacebuilding even amenable to such reconfiguration or would it lose its meaning and legitimacy? Second, such a radical re-framing of the question of identity and difference also needs to consider the potentially positive aspects of claims to difference. In his defence of essentialism and reification, Inayatullah identifies two main ideas. ${ }^{\text {lxx }}$ First, reification and essentialism provide a basis for communication: we agree on the world that we talk about and can thus share our ideas about it. This is not to argue that the world is not created, but rather to say that it is created (or imagined) as reified. In the case of peacebuilding, such a notion could mean that some identities and some differences should be preserved as the basis for engagement and communication. Second, essentialism and reification can also serve as vantage points for critique and for political claims, especially for dominated groups. This is what Krishna calls "provisional or strategic essentialisms". ${ }^{\text {xxvi }}$ In peacebuilding, it is easy to see how identities and differences are used as political tools in the context of power dynamics and contestations. Some 'local' groups can for instance claim an 'authentic' identity in order to reinforce their position while others can insist on their internationalism ('universalism') to legitimise their claims. Whether the framework presented here is compatible with the overall peacebuilding enterprise and with some of the complex plays of identities and differences that it generates remain an open question. Yet the centrality of the 'problem' of difference for peacebuilding (and international relations more generally) make further research on this concept essential. 


\section{References:}

Anghie, Antony. Imperialism, Sovereignty and the Making of International Law. Cambridge: Cambridge University Press, 2005.

Bargués-Pedreny, Pol. "Connolly and the Never-Ending Critiques of Liberal Peace: From the Privilege of Difference to Vorarephilia." Cambridge Review of International Affairs 30, no. 2-3 (2017): 216-234.

Bargués-Pedreny, Pol, and Xavier Mathieu."Beyond Silence, Obstacle and Stigma: Revisiting the 'Problem' of Difference in Peacebuilding." Journal of Intervention and Statebuilding 12, no. 3 (2018).

Barnett, Michael, Hunjoon Kim, Madalene O'Donnell, and Laura Sitea. "Peacebuilding: What Is in a Name?". Global Governance: A Review of Multilateralism and International Organizations 13, no. 1 (2007): 35-58.

Behr, Hartmut. Politics of Difference: Epistemologies of Peace. London and New York: Routledge, 2014.

Björkdahl, Annika, and Ivan Gusic. "'Global' Norms and 'Local' Agency: Frictional

Peacebuilding in Kosovo." Journal of International Relations and Development 18, no. 3 (2015): 265-87.

Brigg, Morgan. The New Politics of Conflict Resolution Responding to Difference. Basingstoke, New York: Palgrave Macmillan, 2008.

Brigg, Morgan, and Roland Bleiker, eds. Mediating across Difference: Oceanic and Asian Approaches to Conflict Resolution. Honolulu: University of Hawai'i Press, 2011.

Chandler, David. "The Uncritical Critique of 'Liberal Peace'." Review of International Studies 36, no. 1 (2010): 137-55.

Donais, Timothy. "Empowerment or Imposition? Dilemmas of Local Ownership in PostConflict Peacebuilding Processes." Peace and Change: a journal of peace research 34, no. 1 (2009): 3-26.

Donais, Timothy. "Bringing the Local Back In: Haiti, Local Governance and the Dynamics of Vertically Integrated Peacebuilding." Journal of Peacebuilding \& Development 10, no. 1 (2015): 40-55.

Enns, Charis, Brock Bersaglio, and Thembela Kepe. "Indigenous Voices and the Making of the Post-2015 Development Agenda: The Recurring Tyranny of Participation." Third World Quarterly 35, no. 3 (2014): 358-75.

Eriksen, Stein Sundstol. "The Liberal Peace Is Neither: Peacebuilding, State Building and the Reproduction of Conflict in the Democratic Republic of Congo." International Peacekeeping 16, no. 5 (2009): 652-66.

Felix da Costa, Diana, and John Karlsrud. "Contextualising Liberal Peacebuilding for Local Circumstances: Unmiss and Local Peacebuilding in South Sudan." Journal of Peacebuilding \& Development 7, no. 2 (2012): 53-66.

Hameiri, Shahar, and Lee Jones. "Beyond Hybridity to the Politics of Scale: International Intervention and 'Local' Politics." Development and Change 48, no. 1 (2017): 54-77.

Hirblinger, Andreas T, and Claudia Simons. "The Good, the Bad, and the Powerful: Representations of the 'Local' in Peacebuilding." Security Dialogue 46, no. 5 (2015): 422-39.

Hughes, Caroline, and Vanessa Pupavac. "Framing Post-Conflict Societies: International Pathologisation of Cambodia and the Post-Yugoslav States." Third World Quarterly 26, no. 6 (2005): 873-89.

Inayatullah, Naeem. "Gigging on the World Stage: Bossa Nova and Afrobeat after DeReification." Contexto Internacional 38, no. 2 (2016): 523-43.

Kappler, Stefanie. "The Dynamic Local: Delocalisation and (Re-)Localisation in the Search for Peacebuilding Identity." Third World Quarterly 36, no. 5 (2015): 875-89. 
Krishna, Sankaran. "Review: The Importance of Being Ironic: A Postcolonial View on Critical Internationalrelations Theory." Alternatives: Global, Local, Political 18, no. 3 (1993): 385417.

Lee, Sung Yong, and Alpaslan Özerdem, eds. Local Ownership in International Peacebuilding. Key Theoretical and Practical Issues. Oxon and New York: Routledge, 2015.

Leonardsson, Hanna, and Gustav Rudd. "The 'Local Turn' in Peacebuilding: A Literature Review of Effective and Emancipatory Local Peacebuilding." Third World Quarterly 36, no. 5 (2015): 825-39.

Lidén, Kristoffer, Roger Mac Ginty, and Oliver P. Richmond. "Introduction: Beyond Northern Epistemologies of Peace: Peacebuilding Reconstructed?". International Peacekeeping 16, no. 5 (2009): 587-98.

Mac Ginty, Roger. "Where Is the Local? Critical Localism and Peacebuilding." Third World Quarterly 36, no. 5 (2015): 840-56.

Mac Ginty, Roger "Indigenous Peace-Making Versus the Liberal Peace." Cooperation and Conflict 43, no. 2 (2008): 139-63.

. "What Do We Mean When We Use of the Tern 'Local'? Imagining and Framing the Local and the International in Relation to Peace and Order." In Peacebuilding in Crisis: Rethinking Paradigms and Practices of Transnational Cooperation, edited by Tobias Debiel, Thomas Held and Ulrich Schneckener, 193-209. Oxon and New York: Routledge, 2016.

Mac Ginty, Roger, and Christine Sylva Hamieh. "Made in Lebanon: Local Participation and Indigenous Responses to Development and Post-War Reconstruction." Civil Wars 12, no. 1-2 (2010): 47-64.

Mac Ginty, Roger, and Pamina Firchow. "Top-Down and Bottom-up Narratives of Peace and Conflict ". Politics 36, no. 3 (2016): 308-23

Mac Ginty, Roger, and Oliver P. Richmond. "The Fallacy of Constructing Hybrid Political Orders: A Reappraisal of the Hybrid Turn in Peacebuilding." International Peacekeeping 23, no. 2 (2016): 219-39.

Minow, Martha. Making All the Difference: Inclusion, Exclusion, and America Law. Ithaca: Cornell University Press, 1990.

Nadarajah, Suthaharan, and David Rampton. "The Limits of Hybridity and the Crisis of Liberal Peace." Review of International Studies 41, no. 1 (2015): 49-72.

Paffenholz, Thania. "International Peacebuilding Goes Local: Analysing Lederach's Conflict Transformation Theory and Its Ambivalent Encounter with 20 Years of Practice." Peacebuilding 2, no. 1 (2014): 11-27.

. "Unpacking the Local Turn in Peacebuilding: A Critical Assessment Towards an Agenda for Future Research." Third World Quarterly 36, no. 5 (2015): 857-74.

Park, Augustine S. J. "Peacebuilding, the Rule of Law and the Problem of Culture: Assimilation, Multiculturalism, Deployment." Journal of Intervention and Statebuilding 4, no. 4 (2010): 41332.

Randazzo, Elisa. "The Paradoxes of the 'Everyday': Scrutinising the Local Turn in Peace Building." Third World Quarterly 37, no. 8 (2016): 1351-70.

Richmond, Oliver P. "Becoming Liberal, Unbecoming Liberalism: Liberal-Local Hybridity Via the Everyday as a Response to the Paradoxes of Liberal Peacebuilding." Journal of Intervention and Statebuilding 3, no. 3 (2009): 324-44.

. "Beyond Local Ownership in the Architecture of International Peacebuilding." Ethnopolitics 11, no. 4 (2012): 354-75.

. "A Pedagogy of Peacebuilding: Infrapolitics, Resistance, and Liberation." International Political Sociology 6, no. 2 (2012): 115-31.

Richmond, Oliver P., and Roger Mac Ginty. "Where Now for the Critique of the Liberal Peace?". Cooperation and Conflict 50, no. 2 (2015): 171 -89. 
Richmond, Oliver P., and Audra Mitchell. "Peacebuilding and Critical Forms of Agency: From Resistance to Subsistence." Alternatives: Global, Local, Political 36, no. 4 (2011): 326-44.

Sabaratnam, Meera. "Avatars of Eurocentrism in the Critique of the Liberal Peace." Security Dialogue 44, no. 3 (2013): 259-78.

. "Situated Critiques of Intervention: Mozambique and the Diverse Politics of Response." In A Liberal Peace? The Problems and Practices of Peacebuilding, edited by Susanna Campbell, David Chandler and Meera Sabaratnam, 245-64. London: Zed Books, 2011.

Schaefer, Christoph Daniel. "Local Practices and Normative Frameworks in Peacebuilding." International Peacekeeping 17, no. 4 (2010): 499-514.

Schierenbeck, Isabell. "Beyond the Local Turn Divide: Lessons Learnt, Relearnt and Unlearnt." Third World Quarterly 36, no. 5 (2015): 1023-32.

Sending, Ole Jacob. "Why Peacebuilders Fail to Secure Ownership and Be Sensitive to Context." Working paper: Norwegian Institute of International Affairs, 2009.

Simons, Claudia, and Franzisca Zanker. "Questioning the Local in Peacebuilding." Working paper of the Priority Programme 1448 of the German Research Foundation, no. 10 (2014): Leipzig and Halle

Visoka, Gëzim, and Oliver P. Richmond. "After Liberal Peace? From Failed State-Building to an Emancipatory Peace in Kosovo." International Studies Perspectives 18, no. 1 (2017): 110-29.

Vrasti, Wanda. "The Strange Case of Ethnography and International Relations." Millenium: Journal of International Studies 37, no. 2 (2008): 279-301.

Wanis-St. John, Anthony "Indigenous Peacebuilding." In Routledge Handbook of Peacebuilding, edited by Roger Mac Ginty, 360-74. London: Routledge, 2013.

Wilén, Nina, and Vincent Chapaux. "Problems of Local Participation and Collaboration with the Un in a Post-Conflict Environment: Who Are the 'Locals'?". Global Society 25, no. 4 (2011): 531-48. 
i The term 'peacebuilding' is itself contentious and this article cannot offer a full exploration of its meaning(s). Instead, I explore what scholars have argued in relation to peacebuilding and its local actors, recognising that these scholars can have different understandings of the term itself. For an exploration of the different meaning of peacebuilding, see Barnett et al., "Peacebuilding: What is in a name?".

ii The term 'local' is used in the singular in this article to reflect its use in the existing literature. The pronoun 'its' is used when talking about the local in general (including institutions and values) and 'her' when talking about local actors.

iii Leonardsson and Rudd, "The 'Local Turn' in Peacebuilding," 832.

iv Chandler, "The Uncritical Critique of 'Liberal Peace'," 155.

v Björkdahl and Gusic, "'Global' Norms and 'Local' Agency," 282; see other examples in Mac Ginty and Richmond, "The Fallacy of Constructing Hybrid Political Orders," Visoka and Richmond, "After Liberal Peace?".

vi Nadarajah and Rampton, "The Limits of Hybridity," 53.

vii See the useful reviews of this abundant literature in Leonardsson and Rudd "The 'Local Turn' in Peacebuilding", Richmond and Mac Ginty "Where Now for the Critique of the Liberal Peace?," and Randazzo "The Paradoxes of the "Everyday".

viii Bargués-Pedreny, "Connolly and the Never-Ending Critiques of Liberal Peace", 217.

ix See, for example, Sabaratnam "Situated Critiques of Intervention"; Sabaratnam, "Avatars of Eurocentrism in the Critique of the Liberal Peace"; Simons and Zanker "Questioning the Local in Peacebuilding"; Kappler "The Dynamic Local"; Hirblinger and Simons "The Good, the Bad, and the Powerful"; Paffenholz "Unpacking the Local Turn in Peacebuilding"; Randazzo "The Paradoxes of the "Everyday"; and Hameiri and Jones, "Beyond Hybridity to the Politics of Scale".

x Minow, Making All the Difference, 20.

xi Ibid., 112.

xii Ibid., 22.

xiii For exceptions see Brigg, The New Politics of Conflict Resolution; Behr, Politics of Difference; and Bargués-Pedreny and Mathieu, 'Beyond Silence, Obstacle and Stigma'.

xiv Björkdahl and Gusic, "'Global' Norms and 'Local' Agency," 270.

xv Mac Ginty and Richmond, "The Fallacy of Constructing Hybrid Political Orders," 231; see also Schierenbeck, "Beyond the Local Turn Divide." As expressed by Björkdahl and Gusic ("'Global’ Norms and 'Local’ Agency," 272), one of the central concerns for these scholars is "the search for the local agent".

xvi Richmond and Mitchell, "Peacebuilding and Critical Forms of Agency,".

xvii Mac Ginty "Where Is the Local?," 848.

xviii Ginty and Sylva Hamieh, "Made in Lebanon," 47. See also Paffenholz "International Peacebuilding Goes Local" and Leonardsson and Rudd "The 'Local Turn' in Peacebuilding".

xix Björkdahl and Gusic, "'Global' Norms and 'Local' Agency," 267.

xx Mac Ginty, "Where Is the Local?," 841; see also Schierenbeck, "Beyond the Local Turn Divide."

xxi See for instance the analyses assembled in the edited volumes of Lee and Özerdem, Local Ownership in International Peacebuilding and Brigg and Bleiker, Mediating Across Difference, as well as (among many others) Felix da Costa and Karlsrud "Contextualising Liberal Peacebuilding for Local Circumstances" and Eriksen, "The Liberal Peace is Neither".

xxii Mac Ginty, "Where Is the Local?,": 841-42; see also Björkdahl and Gusic, "'Global' Norms and 'Local' Agency," 269.

xxiii Wilén and Chapaux, "Problems of Local Participation and Collaboration," 534.

xxiv Mac Ginty, "Where Is the Local?"; Björkdahl and Gusic, "'Global' Norms and 'Local' Agency"; Mac Ginty and Firchow, "Top-Down and Bottom-up Narratives of Peace and Conflict"; and for a more problem-solving approach recognising the ambiguities of the local see Schaefer, "Local Practices and Normative Frameworks in Peacebuilding".

xxv Schierenbeck, "Beyond the Local Turn Divide," 1032.

xxvi See for instance Wanis-St. John "Indigenous Peacebuilding," 363.

xxvii Björkdahl and Gusic,"'Global' Norms and 'Local' Agency," 282.

xxviii Mac Ginty, "Where Is the Local?," 848. See also Schierenbeck (Beyond the Local Turn Divide," 1024) who recognises the potential impossibility of accessing the local: "we need to ask ourselves how we as outsiders, interveners and policy makers can (if we can) interpret, comprehend and understand the local".

xxix Mac Ginty and Richmond, "The Fallacy of Constructing Hybrid Political Orders," 233.

xxx Mac Ginty cited in Leonardsson and Rudd, "The 'Local Turn' in Peacebuilding," 834.. For more references to the acknowledgement of failures by critical scholars see Bargués-Pedreny "Connolly and the Never-Ending Critiques of Liberal Peace". 
xxxi Lidén et al., "Introduction: Beyond Northern Epistemologies of Peace," 593.

xxxi Hughes and Pupavac, "Framing Post-Conflict Societies".

xxxii It will also be unlikely to cover or include all the other forms of difference existing inside the category 'women'.

xxxiv Minow, Making All the Difference, 4.

xxxv Mac Ginty, "What Do We Mean When We Use of the Term 'Local'?," 207.

xxxvi Sending, "Why Peacebuilders Fail to Secure Ownership and Be Sensitive to Context," 21. See also Wanis-St. John "Indigenous Peacebuilding."

xxxvii Björkdahl and Gusic, "'Global' Norms and 'Local' Agency."

xxxviii Hameiri and Jones, "Beyond Hybridity to the Politics of Scale."

xxxix Richmond, "Becoming Liberal, Unbecoming Liberalism," 333-34.

xl Lidén et al., "Introduction: Beyond Northern Epistemologies of Peace," 594, emphasis added.

xli Mac Ginty, "Indigenous Peace-Making Versus the Liberal Peace," 143, emphasis added.

xlii Ibid., 149; Mac Ginty and Sylva Hamieh, "Made in Lebanon," 59.

xliii Schierenbeck, "Beyond the Local Turn Divide," 1027.

xliv Schaefer, "Local Practices and Normative Frameworks in Peacebuilding," 512.

xlv Donais, "Empowerment or Imposition?," 11; see also Mac Ginty, "Indigenous Peace-Making Versus the Liberal Peace," 151.

xlvi Richmond, "A Pedagogy of Peacebuilding," 119.

xlvii Mac Ginty, "Indigenous Peace-Making Versus the Liberal Peace," 159.

xlviii Richmond, "Beyond Local Ownership in the Architecture of International Peacebuilding," 364.

xlix Richmond, "Becoming Liberal, Unbecoming Liberalism," 335.. This is directly opposed to the standardised approach of "universal liberalism" and its disregard for "cultural identity" (ibid., 334).

${ }^{1}$ Donais, "Empowerment or Imposition?," 20; Richmond, "A Pedagogy of Peacebuilding," 126.

li On the question of the import of 'Anthropology' into International Relations see Vrasti "The Strange Case of Ethnography and International Relations."

lii Schierenbeck, "Beyond the Local Turn Divide," 1030.

liii Felix da Costa and Karlstud "Contextualising Liberal Peacebuilding for Local Circumstances," 61.

liv Wanis-St. John, "Indigenous Peacebuilding," 365.

lv Visoka and Richmond "After Liberal Peace?," 114 and 21. On de-politicisation see Nadarajah and Rampton's critique of the exclusionary tendencies of hybrid peace approaches and their valorisation of 'consensual', 'a-political' solutions (Nadarajah and Rampton, "The Limits of Hybridity and the Crisis of Liberal Peace," 65).

lvi For examples of how the inclusion of the local can be limited to the 'complying' local or to the folkloric aspects of the local, see Enns et al., "Indigenous Voices and the Making of the Post-2015 Development Agenda" and Park, "Peacebuilding, the Rule of Law and the Problem of Culture".

lvii This does not mean that 'difference' does not exist; rather, it points at the fact that out of the near infinity of ways people can be classified only some of them are considered relevant depending on the situation and context: religious affiliation, gender identity, group membership, etc.

lviii Anghie, Imperialism, Sovereignty and the Making of International Law.

lix Minow, Making All the Difference, 112.

lx Minow, Making All the Difference, 70.

Ixi Mac Ginty and Richmond. "The Local Turn in Peace Building," 770; Richmond and Mac Ginty. "Where Now for the Critique of the Liberal Peace?" 172.

lxii Mac Ginty, "Indigenous Peace-Making," 145.

liiii Richmond, "A Pedagogy of Peacebuilding," 117.

lxiv Mac Ginty, "Indigenous Peace-Making," 155.

lxv Ibid., 21.

lxvi Mac Ginty and Richmond, "The Fallacy of Constructing Hybrid Political Orders," 232.

kvii Nadarajah and Rampton, "The Limits of Hybridity," 55-56.

lxviii Donais, "Bringing the local back in", 42.

lxix Ibid., 219.

lxx Ibid., 23.

Ixxi Ibid., 390.

lxxii Ibid., 75.

lxxiii Mac Ginty, "Where Is the Local?," 848.

lxxiv Minow, Making All the Difference, 390.

lxxv Inayatullah, "Gigging on the World Stage."

lxxvi Krishna, "Review: The Importance of Being Ironic," 401. 